\title{
DAS MARGENS DOS RIOS À MARGEM DA SOCIEDADE: TRAJETÓRIAS DE MULHERES SATERÉ-MAWÉ NO TRABALHO DOMÉSTICO EM MANAUS, AM
}

\author{
FROM THE RIVER BANKS AT THE EDGE OF SOCIETY: TRAJECTORIES OF \\ SATERÉ-MAWÉ WOMEN IN DOMESTIC WORK IN MANAUS, AM
}

\author{
W. R. M. ARAÚJO 1
}

1 Universidade Federal do Amazonas, Mestrado em Sociedade e Cultura na Amazônia, Brasil

\section{AR T ICLE I N F O}

Article history:

Received 2018-09-09

Accepted 2018-08-17

Available online 2018-08-31

${ }^{\star}$ Autor correspondente:

E-mail: marquesreis@hotmail.com
Palavras-chave: $\quad$ Mulher Indígena. Trabalho doméstico. Comunidade Sateré-Mawé.

Keywords: Indigenous Woman. Housework. Sateré - Mawé Community.

Resumo. Esta pesquisa assumiu o propósito de verificar a situação às quais são submetidas as mulheres indígenas que saem de suas comunidades tradicionais para se inserirem no trabalho doméstico em Manaus. Buscamos também reconstruir fragmentos da história de vida e de trabalho de duas mulheres Sateré-Mawé, dona Zenilda e Zeila (Kutera), que se deslocaram de sua comunidade étnica de origem em busca de educação formal, saúde ou renda em Manaus, durante o período de instalação da Zona Franca. Diante da falta de oportunidades de trabalho formal, elas se inseriram no trabalho doméstico. Mesmo assim, podemos verificar pelas suas trajetórias de vida, que elas tornaram-se duas lideranças femininas de grande projeção dentro do movimento indígena. As questões norteadoras desta pesquisa consistiram em verificar quais são as determinações étnicas e de gênero presentes no trabalho doméstico em Manaus, capital do Estado do Amazonas. Adotamos uma metodologia que nos levou a considerar os aspectos qualitativo e exploratório, quando a fala dos sujeitos foi imprescindível para a reconstrução de aspectos da trajetória de vida e de trabalho das mulheres da etnia Sateré-Mawé. Foram realizadas entrevistas abertas com cinco mulheres da etnia 
Sateré-Mawé, além da observação direta na Comunidade l'nhaã-bé, durante o período de abril de 2009 a agosto de 2010. Elegemos um referencial teórico que problematiza as questões de gênero que são determinantes na situação desfavorável que se encontra esse segmento humano. O conceito de gênero é empregado como uma categoria construída social e culturalmente, que envolve relações de poder sob os auspícios do patriarcado. A pesquisa mostra que há uma forte ressignificação na vida dessas mulheres que se deslocaram para a cidade, as quais vivem no limiar do urbano e do rural. Conclui-se, assim, que para muitas mulheres do interior amazônico o trabalho doméstico passa a ser o caminho para chegar às cidades. Essa situação as envolve numa teia de exploração permeada por questões de gênero sob o forte preconceito étnico. O eixo norteador desta pesquisa tomou o rio não apenas como uma metáfora que demarca a trajetória de deslocamento e o espaço ocupado na cidade pelos indígenas, mas também pela situação de margem (marginalidade) social que esses agentes sociais estigmatizados se encontram no espaço urbano de Manaus. Os nativos amazônicos que se deslocam para o espaço urbano se vêem à margem da sociedade desprovidos da sua capacidade produtiva e de suas redes de relações sociais. Nas suas comunidades de origem, localizadas no interior amazônico, vivem numa relação de interdependência com a terra e com os elementos da natureza, que orientam todo o seu modo de vida. Uma vez inseridos na sociedade envolvente passam, pois, a se constituir em sujeitos sociais heterogêneos do ponto de vista da situação social, econômica e cultural. No espaço urbano esses sujeitos sociais não conseguem exercer efetivamente sua capacidade criadora. Seus modos de reprodução social estão relacionados aos recursos naturais, por isso sua forma de organização social é caracterizada por "modos de produção pré-capitalistas, próprios de sociedades em que o trabalho ainda não se tornou mercadoria, onde há grande dependência dos recursos naturais e dos ciclos da natureza, em que a dependência do mercado já existe, mas não é total" (DIEGUES, 2001, p. 82). Na falta de expectativa de vida, ficam à margem da história, da sociedade e dos processos econômicos da região amazônica. Esse fator contribui ainda mais para se criar uma situação marginal. Numa sociedade que privilegia a produção mercantil de bens e serviços as atividades domésticas, realizadas majoritariamente pelas mulheres, recebem um tratamento discriminado. Não Ihes são garantidas as condições mínimas de subsistência. Este estudo mostra que coube a mulher Sateré-Mawé garantir a substância de suas famílias por meio do trabalho doméstico. Mas o funcionamento e a organização da unidade doméstica, na sociedade ocidental contemporânea, é ainda uma atividade pouco valorizada e invisível pelas próprias características que assume. Além disso, o trabalho das mulheres, que na maioria das vezes é realizado por mediação do seu corpo, é culturalmente associado às funções naturais e biológicas, não sendo socialmente valorizado. Ou seja, todo trabalho das mulheres é considerado uma extensão biológica da procriação e dos cuidados com a prole. Mesmo que o trabalho na casa de família tenha possibilitado aos parentes destas mulheres saírem da aldeia e vir para a cidade, ele foi desempenhado nas condições mais adversas e com diferentes tipos de relação, frente a uma legislação precária, no que se refere às garantias trabalhistas. Diante dessas condições, elas foram compelidas a buscar no trabalho artesanal os meios de sua subsistência. Outro aspecto constatado na pesquisa diz respeito a capacidade organizativa e de liderança dessas mulheres. Zenilda da Silva Vilácio, participou da criação de várias organizações indígenas, especialmente a Associação das Mulheres Indígenas Sateré-Mawé (AMISM), da qual era coordenadora geral. Ela esteve presente também em vários eventos regionais, nacionais e internacionais, tendo viajado por vários estados brasileiros e por outros países. No fim da década de 80, ela tomou parte, juntamente com outros Sateré-Mawé que moravam na cidade, da luta do movimento indígena pela demarcação das terras indígenas. A história de vida e trabalho de Zeila Carvalho Vieira é marca por quatro momentos distintos: a saída da aldeia, sua história familiar; a busca de subsistência através do trabalho doméstico e o trabalho com o artesanato indígena; por fim, a organização da comunidade étnica. Coube-Ihe desempenhar o papel de matriarca, liderança e mulher indígena que sempre esteve preocupada com a preservação da cultura tradicional Sateré-Mawé. Mas a conjuntura criada após a sua morte precoce, modificou sensivelmente a estrutura social da Comunidade I'nhaã-bé. Diante dessas constatações, podemos afirmar que apesar das experiências negativas no trabalho doméstico, Zeila e Zenilda buscaram outras estratégias econômicas a fim de garantir a subsistência 
da família extensa. O estudo mostra que em função da falta de oportunidades de trabalho, elas passam a fabricar e vender artesanato indígena. As vidas dessas irmãs se sangue começam a mudar, segundo as suas narrativas e também a daqueles que conviveram com elas, a partir do momento em que começam se organizar e tecer uma rede de relações sociais (culturais, políticas e econômicas) com outras mulheres. Ao logo deste estudo vivemos um intenso processo de aprendizagem ao buscar compreender a trajetória de mulheres guerreiras.

ABSTRACT. His research was undertaken to verify the situation to which indigenous women who leave their traditional communities are subjected to work in Manaus. We also sought to reconstruct fragments of the life and work history of two Sateré-Mawé women, Dona Zenilda and Zeila (Kutera), who moved from their ethnic community of origin in search of formal education, health or income in Manaus during the period the installation of the Free Trade Zone. Faced with a lack of formal work opportunities, they became part of domestic work. Even so, we can verify by their life trajectories that they have become two female leaders of great projection within the indigenous movement. The guiding questions of this research were to verify the ethnic and gender determinations present in the domestic work in Manaus, capital of the State of Amazonas. We adopted a methodology that led us to consider the qualitative and exploratory aspects, when the subjects' speech was essential for the reconstruction of aspects of the life and work trajectory of Sateré-Mawé women. Open interviews were conducted with five Sateré-Mawé women, in addition to direct observation in the I'nhaã-bé community, from April 2009 to August 2010. We chose a theoretical framework that problematizes the gender issues that are determinant in the unfavorable situation that this human segment is in. The concept of gender is employed as a socially and culturally constructed category involving power relationships under the auspices of patriarchy. Research shows that there is a strong resignification in the lives of these women who have moved to the city, which live on the edge of urban and rural. It is concluded, therefore, that for many women of the Amazonian interior the domestic work becomes the way to reach the cities. This situation involves them in a web of exploitation permeated by gender issues under strong ethnic prejudice. The guiding axis of this research took the river not only as a metaphor that demarcates the trajectory of displacement and the space occupied in the city by the Indians, but also by the situation of margin (social marginality) that these stigmatized social agents are in the urban space of Manaus. Amazonian natives who move to urban space are seen on the margins of society deprived of their productive capacity and their networks of social relations. In their communities of origin, located in the Amazonian interior, they live in a relationship of interdependence with the earth and with the elements of nature that guide their whole way of life. Once inserted in the surrounding society, they become, therefore, constituted in heterogeneous social subjects from the point of view of the social, economic and cultural situation. In urban space these social subjects cannot effectively exercise their creative capacity. Their modes of social reproduction are related to natural resources, so their form of social organization is characterized by "pre-capitalist modes of production, typical of societies in which work has not yet become a commodity, where there is great dependence on natural resources and of the cycles of nature, in which market dependence already exists, but is not total "(DIEGUES, 2001, 82). In the absence of life expectancy, they are at the margin of history, society and economic processes in the Amazon region. This factor further contributes to creating a marginal situation. In a society that favors the mercantile production of goods and services domestic activities, carried out mainly by women, receive discriminated treatment. They are not guaranteed the minimum conditions of subsistence. This study shows that it was up to the Sateré-Mawe woman to guarantee the substance of their families through domestic work. But the functioning and organization of the domestic unit in contemporary Western society is still an activity that is undervalued and invisible by the very characteristics it assumes. Moreover, the work of women, which is most often accomplished through the mediation of their bodies, is culturally associated with natural and biological functions and is not socially valued. That is, all women's work is considered a biological extension of procreation and childcare. Even though the work in the family home made it possible for the relatives of these women to leave the village and come to the city, it was performed under the most adverse conditions and with different types of relationship, in the face of precarious legislation, with regard to labor guarantees. Faced with these conditions, they were compelled to seek in their craft the means of subsistence. Another aspect verified in the research concerns the organizational and leadership capacity of these 
women. Zenilda da Silva Vilácio, participated in the creation of several organizations indigenous especially the Sateré-Mawé Indigenous Women's Association (AMISM), of which she was the general coordinator. She was also present in several regional, national and international events, having traveled through several Brazilian states and by other countries. In the late 1980s, she and other Sateré-Mawé who lived in the city took part in the indigenous movement's struggle to demarcate indigenous lands. The life and work story of Zeila Carvalho Vieira is marked by four distinct moments: the departure of the village, its family history; the search for subsistence through domestic work and work with indigenous crafts; and finally, the organization of the ethnic community. She had to play the role of matriarch, leadership and indigenous woman who had always been concerned with the preservation of the traditional Sateré-Mawé culture. But the conjuncture created after his early death significantly modified the social structure of the l'nhaã-bé community. In view of these findings, we can say that despite negative experiences in domestic work, Zeila and Zenilda sought other economic strategies in order to guarantee the subsistence of the extended family. The study shows that because of the lack of job opportunities, they started to manufacture and sell indigenous handicrafts. The lives of these blood sisters begin to change, according to their narratives and also those of those who lived with them, from the moment they begin to organize and weave a network of social relations (cultural, political and economic) with other women. At the beginning of this study, we experienced an intense learning process in order to understand the trajectory of female.

\section{Referências:}

ARAUJO, W. R. M. Das margens dos rios à margem da sociedade: trajetórias de mulheres Sateré-Mawé no trabalho doméstico em Manaus, AM. Dissertação. Manaus, 2010. Dissertação. (Mestrado em Sociedade e Cultura da Amazônia). Universidade Federal do Amazonas. 